\title{
Service Quality, Profitability, and the Economic Worth of Customers: What We Know and What We Need to Learn
}

\author{
Valarie A. Zeithaml \\ University of North Carolina at Chapel Hill
}

In the past, expenditures on quality have not been explicitly linked to profits because costs and savings were the only variables on which information was available. More recently, evidence about the profit consequences of service quality stemming from other sources has been found. This article synthesizes recent evidence and identifies relationships between service quality and profits that have been and need to be examined. The article views the literature in six categories: (1) direct effects of service quality on profits; (2) offensive effects; (3) defensive effects; (4) the link between perceived service quality and purchase intentions; (5) customer and segment profitability; and (6) key service drivers of service quality, customer retention, and profitability. In each category, the author identifies what is known and then suggests an agenda of relationships needing validation and questions needing answers. The article is organized around a conceptual framework linking the six topics.

Despite the quality revolution that has preoccupied the thinking of American industry, the first decade of service quality improvements was not explicitly linked to profit implications (Aaker and Jacobson 1994) because the evidence was not readily attainable. Because cost and cost savings due to quality were more accessible, they were the main financial variables considered (see, e.g., Bohan and Horney 1991; Carr 1992; Crosby 1979; Deming 1986). In the past decade, however, researchers and companies have

Journal of the Academy of Marketing Science.

Volume 28, No. 1, pages 67-85.

Copyright $\mathcal{C} 2000$ by Academy of Marketing Science. sought and found evidence about the profit consequences of service quality. In fact, the service concern of highest priority to today's companies is the impact of service quality on profit and other financial outcomes of the organization (Greising 1994; Rust, Zahorik, and Keiningham 1995).

The relationship between service and profits took time to verify, part of the delay due to the unfounded expectation that the connection was simple and direct. Investments in service quality, however, do not track directly to profits for a variety of reasons. First, in much the same way as advertising, service quality benefits are rarely experienced in the short term and instead accumulate over time, making them less amenable to detection using traditional research approaches. Second, many variables other than service improvements (such as pricing, distribution, competition, and advertising) influence company profits, leading the individual contribution of service to be difficult to isolate. Third, mere expenditures on service are not what lead to profits; instead, spending on the right variables and proper execution are responsible. The link between service quality and profits is neither straightforward nor simple (Greising 1994; Zahorik and Rust 1992), and no single researcher or company has defined the relationship fully. Instead, different scholars have studied aspects of the connection.

The overall goal of this article is to synthesize existing research and company evidence and to identify relationships between service quality and profits that need to be examined. The specific objectives of this article are the following:

1. To review the recent literature about the relationship between service quality and profitability; 


\begin{tabular}{lll}
\hline Topic Research Research Finding &
\end{tabular}

Service quality and profitability: The direct relationship

\section{Negative evidence}

Matthews and Katel (1992)

A. T. Kearney ("The Cracks in Quality" 1992)

Arthur D. Little ("The Cracks in

Quality" 1992)

Easton (1993)

Bounds, York, Adams, and Ranney (1994)

Reger, Gustafson, Demarie, and

Mulland (1994)

Greising (1994)

Ittner and Larcker (1996)

Sterman, Repenning, and Kofman (1997)

Positive evidence

Koska (1990)

Ford Motor Company (1990)

U.S. General Accounting Office (1991)

Rust, Subramanian, and Wells (1992) Nelson et al. (1992)

Aaker and Jacobson (1994)

Anderson, Fornell, and Lehmann (1994)

Ittner and Larcker (1996)

Hendricks and Singhal (1997)

Easton and Jarrell (1998)
McKinsey and Company found that nearly two thirds of the quality programs that it examined had either stalled or fallen short of delivering real improvements. Eighty percent of more than 100 British firms reported "no significant impact as a result of TQM [Total Quality Management]."

Almost two thirds of 500 U.S. companies saw "zero competitive gain" from TQM.

Departmental self-interest and turf battles led to lack of effectiveness of quality programs.

Implementation problems led quality to fail to affect business performance.

Implementation problems led quality to fail to affect business performance.

Only a few firms that were contacted for a story on the relationship between quality and financial performance could provide documentation. Internal process orientation was often to blame.

Only 29 percent of executive respondents stated that they could link quality to accounting returns such as return on assets, and only 12 percent could link their TQM initiatives to stock price returns or the creation of economic value for shareholders.

Many quality strategies failed to deliver anticipated business performance improvements in many companies.

Strong link between perceived quality of patient care and profitability across Hospital Corporation of America's multiple hospitals.

Dealers with high service-quality scores had higher-than-normal profit, return on investment, and profit per new vehicle sold.

Baldrige National Quality Award competition; found increases in 34 of 40 measurements of market share, sales per employee, return on sales, and retum on assets.

Documented the financial impact of complaint recovery systems

Found a positive relationship between patient satisfaction and hospital profitability. Showed that discrete dimensions (billing, discharge processes) explained 17 to 27 percent of the variation in financial measures such as hospital earnings, net revenues, and retum on assets.

Found a significant positive relationship between stock return and changes in quality perceptions (controlling for the effects of advertising expenditures, salience, and return on investment). Found that the explanatory power of the quality measure compares to that of return on investment.

Using Swedish Customer Satisfaction Barometer and a sample of 77 firms representing 70 percent of Sweden's economic output, found a significant association between customer satisfaction and accounting return on assets (ROA). Controlling for time-series trends and past ROA, customer satisfaction had a statistically positive relationship with current ROA. Elasticity between ROA and customer satisfaction was 0.40 .

Using a small sample of firms from the Swedish study investigated in Anderson et al. (1994), found that shareholder value is highly elastic with respect to customer satisfaction. Correlating the 1994 American Customer Satisfaction Index (ACSI) results of 130 publicly traded firms with available accounting and stock price data, found positive correlations between customer variables (satisfaction, repurchase intention, perceived quality, perceived value, and loyalty) with financial measures (ROA, market-to-book ratio, and price-earnings ratio).

Found strong evidence that firms that have won quality awards outperform control firms on operating income-based measures. During a 10-year period, mean (median) change in the operating income for the test sample is 107 percent higher than that of the control sample.

Found that quality improvement was related to overall corporate performance. 


\section{TABLE 1 Continued}

Topic service quality

Defensive effects of service quality

\section{Research}

Phillips, Chang, and Buzzell (1983)

Buzzell and Gale (1987)

Jacobson and Aaker (1987)

Gale (1992)

Kordupleski, Rust, and Zahorik (1993) Peters (1988)

Fornell and Wernerfelt (1987)

Fornell and Wernerfelt (1988)

Reichheld and Sasser (1990)

Rose (1990)

Anderson and Sullivan (1993)

Rust and Zahorik (1993)

Fornell (1992)

Danaher and Rust

(1996a, 1996b)

Hallowell (1996)

Heskett, Sasser, and Schlesinger (1997)

Rucci, Kirn, and Quinn (1998)

Reichheld (1996b)

service quality and behavioral intentions
Research Finding

Using the Profit Impact of Marketing Strategies (PIMS) database, found that superior quality enhances business performance via market position.

Using the PIMS database, found that perceived quality translates into higher-thannormal market share growth.

Using the PIMS database, found that product quality is positively associated with higher market share and the ability to charge a higher price.

Businesses in the top quintile of relative service quality on average realize an $\mathbf{8}$ percent higher price than their competitors.

Showed the linkages between product quality, service quality, and market share. Selling costs for existing customers are much lower (on average $20 \%$ as much) as selling to new customers (from U.S. Department of Customer Affairs Study).

Examined the impact of complaint-handling programs on customer retention and concluded that marketing resources are better spent on keeping existing customers than getting new ones.

Developed a formula for the market share gains associated with complaint management in a differentiated oligopoly, thereby demonstrating that complaint management can be effective for customer retention.

Identified four intermediate variables (cost, increased purchases, price premiums, word of mouth) that increased with retention, leading to higher profits. Provided evidence from multiple companies in different industries to document the relationship between retention and and profits, reporting that customer loyalty can produce profit increases from 25 to 85 percent.

In the credit card industry, found that profit on services purchased by a 10-year customer were on average three times greater than for a 5-year customer.

Found a positive relationship between customer retention and profits.

Demonstrated the relationship between customer satisfaction and customer retention in a retail bank setting.

Documented the aggregate financial implications of customer satisfaction in a Swedish study, finding a significant relationship between customer satisfaction and increased loyalty of customers, reduced price elasticities, lower transaction costs in providing the service to the customer.

Demonstrated empirically that service quality affects initial customer attraction through word-of-mouth communication. Service quality affected "likeliness to recommend," which affected customer attraction. While advertising also had an impact on attraction, customer usage rates were driven by service quality rather than by advertising.

Documented that customer satisfaction is significantly related to customer loyalty in a bank setting and that loyalty is related to profitability in seven of eight regressions conducted.

Conceptualized the "service-profit chain" and demonstrated that customer defections have a stronger impact on a company's profits than economies of scale, market share, unit costs and other factors.

Using a system of measurements called Total Performance Indicators involving customer satisfaction, employee satisfaction, and profits, documented a turnaround at Sears from 1992 to 1993 . Sales increased by 9 percent and 1-year shareholder return increased by 56 percent. These profit increases were linked to customer and employee satisfaction increases.

"Very satisfied" customers were six times more likely to repurchase Xerox equipment than satisfied customers.

Found a positive correlation between service quality and purchase intentions. Found that stated repurchase intention is strongly related to stated satisfaction across product categories.

Found a significant association between overall patient satisfaction and intent to choose a focal hospital again.

Found a positive and significant relationship between customers perceptions of service quality, and (1) their willingness to recommend the company and (2) their purchase intentions.
Parasuraman, Zeithaml, and Berry

(1988); Zeithaml, Berry, and

Parasuraman (1996) 
TABLE 1 Continued

Topic Research Research Finding

Perceptions of service quality and behavioral intentions

Boulding, Kalra, Staelin, and Zeithaml $(1992,1993)$

McLaughlin (1993)

Richardson, Dick, and Jain (1994)

Bolton and Drew (1991a, 1991b)

Storbacka $(1992,1993,1994 a, 1994 b)$

The impact of selecting profitable customers and customer segments

Reichheld (1993)

Grant and Schlesinger (1995)

Storbacka and Luukinen (1996)

Reichheld (1996a, 1996b)

Key drivers of service quality, customer retention, and profits

Rust and Zahorik (1993)

Mann and Kehoe (1994)

Hauser, Simester, and Wernerfelt (1995)

Rust, Zahorik, and Keiningham (1995)

Ittner and Larcker (1997)
Found a positive correlation between service quality and a two-item measure of repurchase intentions and willingness to recommend. Found a positive correlation between service quality and behavioral intentions including saying positive things about a university, planning to contribute money to the class pledge upon graduation, and planning to recommend the school to employers as a place from which to recruit.

Found that the intent to repurchase a Toyota increased from a base of 37 percent to 45 percent with a positive sales experience, from 37 percent to 79 percent with a positive service experience, and from 37 percent to 91 percent with both positive sales and service experiences.

Perceived quality affects purchase intentions significantly.

Demonstrated the behavioral implications of customer satisfaction of telephone customers.

Developed a framework enabling the analysis of profitability of particular customer relationships. Focused on the difficult problem of allocating costs to specific relationships. Argued that the most important cost drivers are the episodes (encounters) in relationships and provides a way to systematically analyze relationships (called episodic configuration).

Showed that building a high-loyalty customer base of the "right" customers increased profits. At MBNA, a 5 percent increase in retention grew the company profits 60 percent by the fifth year.

Emphasized the importance of realizing customers' full profit potential. Using a Canadian grocery store context, calculated the impact of expanding the customer base by 2 percent with primary shoppers: a profitability increase of more than 45 percent. Converting 200 secondary customers into primary customers would increase profits by 20 percent.

Found that customer satisfaction was higher among the most unprofitable customers in the customer base and that satisfaction is a function of relationship volume.

Showed that the longer a customer stays with a company, the more the customer is worth. Found that reducing customer defections by as little as 5 points--from 15 to 10 percent-can double profits.

Estimated the impact of continuous improvement on profits in 280 automotive suppliers. Found a 17 percent average increase in profits during a 2 - to 3-year period.

Explored the diminishing returns and market share implications of quality expenditures.

Found that delegated or voluntary teams were particularly effective for improving performance of employees and that statistical process control was particularly effective for improving processes.

Demonstrated analytically the financial implications of using customer satisfaction in employee incentive systems.

Provided a framework for examining the impact of service quality improvements on profits and used a simulation to demonstrate the impact on profits. Showed that behavioral impact stemming from service quality leads to improved profitability and other financial outcomes.

Explored the cross-sectional association between process management techniques and profit measures: return on assets and return on sales. Found that long-term partnerships with suppliers and customers are associated with higher performance. Other techniques, such as statistical process control, process capability studies, and cycle time analysis, vary by industry and are not universally related to return on assets and return on sales.
2. to assess the evidence and identify what is currently known about service quality and the economic worth of customers;

3. to present a conceptual framework that links the variables; and
4. to propose a research agenda of the relationships that require further validation and the questions that remain to be explored.

The article begins by describing evidence found to date about the direct relationship between service quality and 
Service quality and profitability: The direct realtionship

Offensive effects of service quality

Defensive effects of service quality

Perceptions of service quality, behavioral intentions, and profits

The impact of distinguishing among tiers of customers
1. What methodologies need to be developed to allow us to capture the impact of service quality on profit?

2. What measures are necessary to examine the relationship in a consistent, valid, and reliable manner?

3. Does the relationship between service quality and profitability vary by industry, country, category of business (e.g., in-services companies versus goods companies, in industrial versus packaged goods companies) or other variables?

4. What are the moderating factors of the relationship between service quality and profitability?

5 . What is the optimal spending level on service to maximize profitability?

1. What is the optimal amount of spending on service quality to obtain offensive effects on reputation?

2. To obtain offensive impact, are expenditures on advertising or service quality itself more effective?

3. In what ways can companies signal high service quality to customers to obtain offensive effects?

1. What is a loyal customer?

2. What is the role of service in defensive marketing?

3. How does service compare in effectiveness to other retention strategies such as price?

4. What levels of service provision are needed to retain customers?

5 . How can word-of-mouth communication from retained customers be quantified?

6. What aspects of service are most important for customer retention?

7. How can defection-prone customers be identified?

1. What is the relationship between customer purchase intentions and initial purchase behavior in services?

2. What is the relationship between behavioral intentions and repurchase in services?

3. Does the degree of association between service quality and behavior change at different quality levels?

1. How can existing customers be identified in terms of profitability?

2. How can potential customers be identified in terms of profitability?

3. How can customers be tiered in terms of profitability?

4. What demographic and psychographic variables are most effective in characterizing profitability segments?

5. What service variables are drivers of financial performance in each tier?

Identifying the key drivers of service

1. What service encounters are most responsible for perceptions of service quality?

quality, customer retention, and profits

2. What are the key drivers in each service encounter?

3. Where should investments be made to affect service quality, purchase, retention, and profits?

4. Are key drivers of service quality the same as key drivers of behavioral intentions, customer retention, and profits? profitability. Next, intervening relationships that have been studied are discussed, including (1) offensive effects of service quality, (2) defensive effects, (3) the link between perceptions of service quality and purchase intentions, (4) individual customer and segment profitability, and (5) the key drivers of service quality, customer retention, and profits. Table 1 summarizes the research and findings in all these categories; each of the sections will discuss the research, evaluate its contributions, and propose an inventory of work that remains to be done. Table 2 presents the full inventory of questions to be answered.

\section{SERVICE QUALITY AND PROFITABILITY: THE DIRECT RELATIONSHIP}

At the aggregate level, a growing body of evidence is emerging about the relationship between service quality and profitability. Academically, this research stream began with the Profit Impact of Marketing Strategies (PIMS) cross-sectional company database that enabled researchers to investigate relationships among strategy variables (Buzzell and Gale 1987). One of the major benefits of the PIMS database is that it allowed researchers to examine the impact of service quality on financial outcomes after controlling for the effects of other variables such as price and advertising. Managerially, the research stream began when firms sought documentation that their investments in service quality, and in Total Quality Management (TQM) in general, were paying off. Because individual firms found it difficult to substantiate the impact of their investments, they turned for insight to a group of early studies conducted by management consulting firms that explored effects across a broad sample of firms. The news was not encouraging. McKinsey and Company 
found that nearly two thirds of quality programs examined had either stalled or fallen short of delivering real improvements (Matthews and Katel 1992). In two other studies, A. T. Kearney found that 80 percent of British firms reported no significant impact as a result of TQM, and Arthur D. Little claimed that almost two thirds of 500 U.S. companies saw "zero competitive gain" from TQM ("The Cracks in Quality" 1992).

Partially in response to early versions of these studies, the U.S. General Accounting Office (GAO) in 1991 sought grounds for belief of the financial impact of quality in companies that had been finalists or winners of the Malcolm Baldrige National Quality Award. While an anecdotal rather than a rigorous study, the GAO found that these elite quality firms had benefited in terms of market share, sales per employee, return on sales, and return on assets (ROA). On the basis of responses from 22 companies who won or were finalists in 1988 and 1989, the GAO found that for 34 of 40 financial variables measured in the years the companies won (or were finalists for), the award showed positive performance improvements, while only six measurements were negative or neutral (U.S. General Accounting Office 1991).

More rigorous academic studies soon followed in the early 1990 s, documenting both negative and positive relationships. Studies showing negative or no effects were typically not focused solely on service quality but examined TQM in general. Easton (1993), for example, showed that departmental self-interest and turf battles led to lack of effectiveness in TQM programs in both product and service companies. Bounds, York, Adams, and Ranney (1994) and Reger, Gustafson, Demarie, and Mulland (1994) identified implementation problems that interfered with quality's impact on business performance. Sterman, Repenning, and Kofman (1997) found that a variety of quality strategies failed to deliver anticipated business performance improvements in many companies. Ittner and Larcker (1996) found that only 29 percent of executive respondents could link quality to accounting returns such as ROA, and only 12 percent could link their TQM initiatives to stock price returns or the creation of economic value for shareholders.

Evidence from research also uncovered positive associations. Rust, Subramanian, and Wells (1992) documented the favorable financial impact of complaint recovery systems. Nelson et al. (1992) found a significant and positive relationship between patient satisfaction and hospital profitability. In their study, specific dimensions of hospital service quality, such as billing and discharge processes, explained 17 to 27 percent of the variance in financial measures such as hospital earnings, net revenues, and ROA. Extending the definition of financial performance to include stock returns, Aaker and Jacobson
(1994) found a significant positive relationship between stock return and changes in quality perceptions while controlling for the effects of advertising expenditures, salience, and return on investment (ROI). In their study, the explanatory power of the quality measure compared to that of ROI, which was viewed as strong corroboration of the connection between perceived quality and business performance.

Indications from companies large enough to have multiple outlets also suggested a positive quality-profitability relationship. For example, the Hospital Corporation of America found a strong link between perceived quality of patient care and profitability across its many hospitals (Koska 1990). The Ford Motor Company (1990) also demonstrated that dealers with high service-quality scores have higher-than-normal profit, ROI, and profit per new vehicle sold.

Significant research progress relating customer satisfaction ${ }^{1}$ and financial performance was facilitated using the cross-sectional data collected for the Swedish (Fornell 1992) and American (Fornell, Johnson, Anderson, Cha, and Bryant 1996) Customer Satisfaction Barometers. Fornell (1992) speculated on the financial implications of customer satisfaction in conducting a large Swedish study of the customer satisfaction of 100,000 customers of 100 firms in 30 industries. While the original data collection did not explicitly link satisfaction and financial performance, researchers have subsequently used the satisfaction data in combination with financial performance data to investigate the associations. For example, Anderson, Fornell, and Lehmann (1994) merged the data from the Swedish Customer Satisfaction Barometer and a sample of 77 firms representing 70 percent of Sweden's economic output. They found a significant association between customer satisfaction and accounting ROA, calibrating the elasticity between ROA and customer satisfaction at 0.40 . Using the customer satisfaction data from the same study, Ittner and Larcker (1996) obtained public stock price data from firms where they were available (a much smaller sample) and extended the accounting ROA results to shareholder value. They found exploratory evidence that stock price was highly elastic with respect to customer satisfaction.

Ittner and Larcker (1996) also correlated the 1994 American Customer Satisfaction Index (ACSI) results of 130 publicly traded firms with available accounting and stock price data and documented a positive correlation between customer variables (satisfaction, repurchase intention, perceived quality, perceived value, and loyalty) and financial measures (ROA, market-to-book ratio, and price-earnings ratio). Quality improvement has also been linked in other studies to stock price shifts (Aaker and Jacobson 1994), the market value of the firm (Hendricks 
and Singhal 1997), and overall corporate performance (Easton and Jarrell 1998). ${ }^{2}$

\section{THE DIRECT RELATIONSHIP: WHAT WE DO NOT KNOW}

As documented above, research on the direct relationship between service quality and profits has shown both positive effects in a limited number of studies and no effects in other studies. By no means has this stream of research been exhausted. Among the avenues to pursue are the following:

1. What methodologies need to be developed to allow us to capture the impact of service quality on profit? While the results of these studies are compelling, they stop short of describing systematic methodologies and approaches to fully explicate the relationship (Rust et al. 1995 is a notable exception). Virtually all of the research looking at the associations have been cross-sectional studies spanning companies and industries. Although this approach is invaluable in demonstrating the general relationship, of central interest to academics and scholars, firms are also eager for more managerial evidence of the relationship. Longitudinal approaches that involve satisfaction and financial performance data in individual firms are a needed approach, as are more cross-sectional studies within firms that have multiple outlets such as automobile dealerships and franchises.

2. What measures are necessary to examine the relationship in a consistent, valid, and reliable manner? One of the early impediments to research on service quality was the lack of valid and reliable measures of the construct (Parasuraman, Zeithaml, and Berry 1985). Until those existed, attempts to capture perceived service quality were viewed as haphazard and sloppy. Fifteen years of effort on developing measures of service quality have yielded positive results in terms of reported measurement in the academic literature. However, Ittner and Larcker (1996) severely criticize the psychometric properties of customer measures used within many companies, particularly the statistical reliability and predictive validity of the measures. Because the random variability in a measure is related to the number of scale points used in the measurement (see Cox 1980), the use of 3- to 5-point scales-commonly used in many firms-may be inadequate. Singleitem measures also have much lower reliability than multiple-item measures (Ryan, Buzas, and Ramaswamy 1995). We need to also further define and delineate the aspects of profitability that are to be captured in this research. In the studies described above, a variety of variables were measured including ROI, ROA, and stock price return. To the extent that these can be systematized and studied repeatedly across firms, the body of research on the relationship would be solidified.

3. Does the relationship between service quality and profitability vary by industry, country, category of business (e.g., services versus goods, industrial versus packaged goods) or other variables? One of the most intriguing questions remaining involves the generalizability of the association between perceived service quality and profitability across contexts. Companies are quick to point out that unique or competitive situations in their industries lead to doubts about the validity of research in other contexts to apply to them. Balancing the research across contexts is a priority to substantiate the general relationship and will also answer questions posed by companies about their own contexts.

4. What factors moderate the relationship between service quality and profitability? Recent research, most of it in the management discipline, has identified strategic and implementation variables that account for variance in the relationship between TQM and financial performance (e.g., Easton 1993; Reger et al. 1994). Virtually all of this research obtains both independent and dependent measures from the same source, the organization. This approach is not appropriate for answering questions about the impact of service quality because customer perceptions themselves (rather than managerial perceptions of customer perceptions) should be incorporated. However, linking customer perceptual measurements with organizational variables is difficult methodologically (see Parasuraman, Berry, and Zeithaml 1991a). For that reason, comprehensive studies that incorporate customer perceptions and different organizational variables to explain the variance in performance remain to be conducted.

5. What is the optimal spending level on service to have an impact on profitability? Few, if any, researchers have attempted to identify the optimal spending level for service (see Rust and Zahorik 1993 for an exception). Blattberg and Deighton's (1996) calculations about optimal acquisition and retention spending offer a methodology for addressing this question, although they did not isolate service spending. Extensions to their model, however, could do so.

\section{OFFENSIVE EFFECTS OF SERVICE QUALITY}

Figure 1 shows a conceptual model that delineates the variables involved in the relationship between service quality and profits. Fornell and Wernerfelt $(1987,1988)$ have defined the term offensive effects as the impact of service on obtaining new customers. Only a small set of studies exists on offensive effects, usually involving the relationship between service quality and antecedents of 


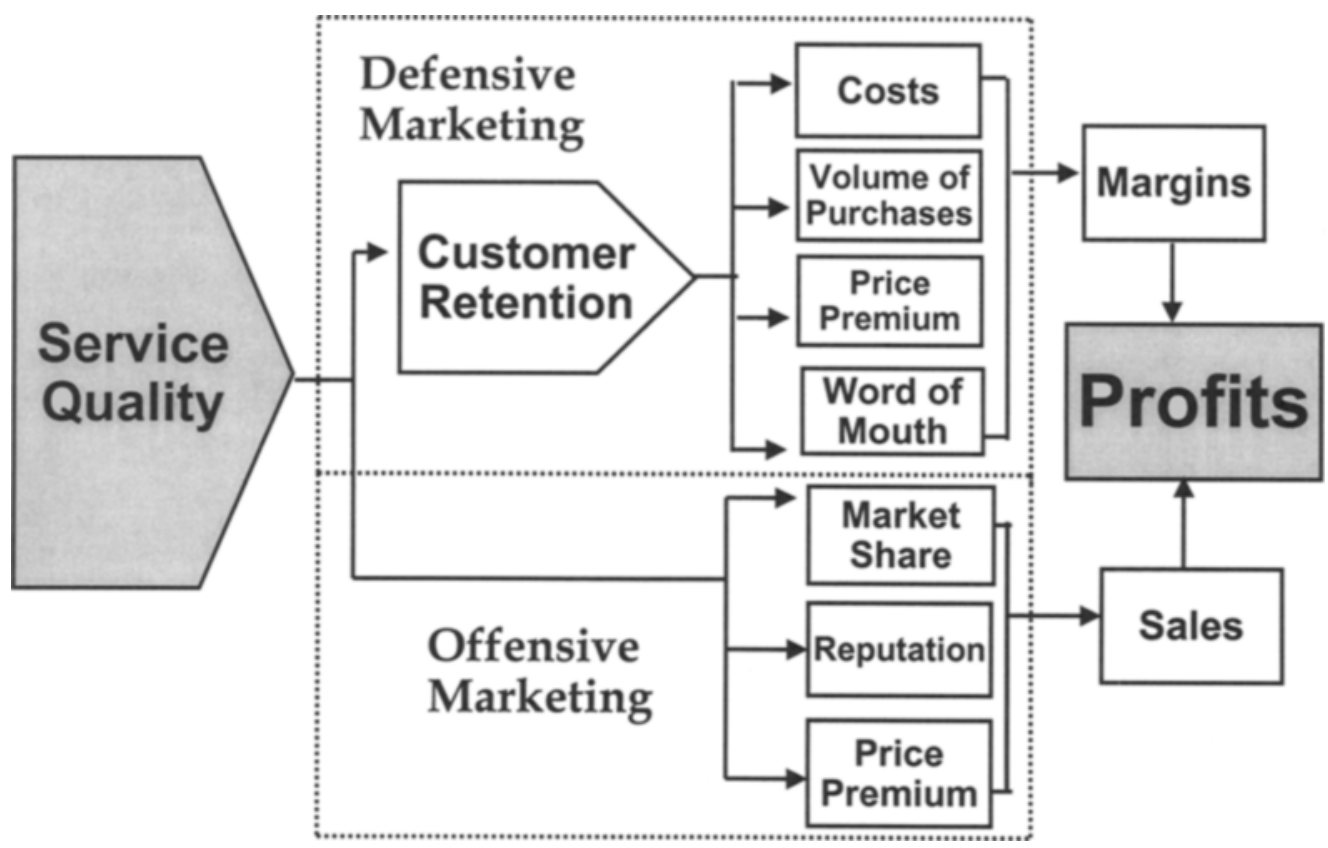

profitability such as market share, firm reputation, and the ability to command a price premium. Virtually all of these studies are at the aggregate level examining a cross section of firms. Seminal studies using the PIMS database uncovered significant associations among service quality, marketing variables, and profitability. Findings from these studies showed that companies offering superior service achieve higher-than-normal market share growth (Buzzell and Gale 1987) and that the mechanisms by which service quality increased profits included higher market share and premium prices (Phillips, Chang, and Buzzell 1983). In one study, Gale (1992) found that businesses in the top quintile of relative service quality on average realized an 8 percent higher price than their competitors. Using a reanalysis of the PIMS data, Jacobson and Aaker (1987) showed that product quality was positively associated with higher market share, the ability to charge a higher price, and increased ROI.

One of the major criticisms leveled at PIMS research, and one with high relevance to linking service quality and profits, is that in PIMS, perceived service quality is reported from the firm's perspective rather than the customer's perspective. While we can therefore connect the firm's perception of the customer's perception of service quality and profits, this is not the relationship between customer-perceived quality and profits. Difficulties in data collection, specifically connecting customer data with firm data, impede these research efforts.

Kordupleski, Rust, and Zahorik (1993) conceptually delineated the path between quality and market share, claiming that satisfied customers spread positive word of mouth, which leads to the attraction of new customers and then to higher market share. They claim that advertising without sufficient quality to back up the communications will not increase market share. Furthermore, they contend that there are time lags in market share effects, making the relationship between quality and market share difficult to discern in the short term.

\section{OFFENSIVE EFFECTS OF SERVICE QUALITY: WHAT WE DO NOT KNOW}

Except for the results of the PIMS data found in the 1980 s, there is virtually no empirical research support for the offensive impact of service quality. Instinct and the evidence from the PIMS studies suggest that service quality improves reputation, market share, sales, and the ability to charge premium prices, yet confirmation in the form of research is sparse. Among the questions that most require answers are the following:

1. What is the optimal amount of spending on service quality to obtain offensive effects on reputation? Possessing 
a good reputation is indisputably one of the most critical factors in customer choice, so service firms are tremendously interested in the role of service-and consequently the role of service spending -in achieving a strong reputation (see, e.g., Andreassen and Lindestad 1998). One of the difficult issues will be to isolate the amount of company spending on service because so many different approaches and processes are involved in delivering service quality. Perhaps the most promising approach would be to examine amounts of money spent on identifiable components of service delivery-such as service quality training, employee compensation, customer research, internal marketing - and relate these individual variables to firm reputation. The difficulty in this type of research, as mentioned above, is that the linkage between spending and reputation is most accurate if data about spending come from firms and meaningful if perceived reputation comes from customers. In a methodological sense, relating these data is difficult. An innovative and compelling approach may be to collect data from both companies and their customers, asking both to report on both sets of variables (spending on service quality and perceived reputation), then comparing the perceptions of the two groups on both sets of variables.

2. To obtain offensive effects, are expenditures on advertising or service quality itself more effective? Much of the literature on brand equity portrays the role of advertising as central. Expenditures on advertising to create brand images are viewed to be both necessary and effective. An interesting question in a service-quality context is whether expenditures on advertising are more effective than expenditures on service quality itself to obtain offensive effects such as reputation and the ability to command a price premium. Many researchers claim that word of mouth is more pivotal than advertising in services (e.g., Danaher and Rust 1996a, 1996b; Kordupleski et al. 1993), yet conditions may dictate situations where advertising is the preferred strategy. One research hypothesis might be that advertising has a higher impact in certain situations, such as with services high in search or experience properties (Nelson 1970) but not as strong as with services high in credence properties (Darby and Karni 1973; Zeithaml 1981). Another hypothesis might be that advertising's impact is more potent in initial purchases rather than with repeat purchases and with new services rather than with existing services. Yet another hypothesis is that the hierarchy of effects operates differently for services and goods; for example, advertising of services might be more useful for awareness but less useful for later stages.

3. In what ways can companies signal high service quality to customers to obtain offensive effects? The signaling effect of advertising has long been acknowledged by economists (Nelson 1970) and others, and the appropriate messages and signals to convey reputation and worth so as to induce trial and willingness to pay a price premium are fertile areas for research. The signaling effect of price on quality has also been heavily studied. Other cues that might signal service quality-the impact of tangibles, brand name, media vehicles, media spending, and other cues-have been mentioned as important and in some cases confirmed as critical to purchase, yet not always explicitly in the service context.

\section{DEFENSIVE EFFECTS OF SERVICE QUALITY}

Anecdotes about the superior financial value of existing customers over new customers are ubiquitous. Two of the most frequently espoused are that it costs 5 times as much to obtain a new customer as to keep an existing one and that selling costs for existing customers are much lower (on average $20 \%$ lower) than selling to new ones (Peters 1988). When it comes to keeping the customers a firm already has, an approach called "defensive marketing" (Fornell and Wernerfelt 1987, 1988), researchers and consulting firms have in the past 10 years documented and quantified the financial impact of existing customers. Among their findings are that numerous intervening variables can be isolated, calibrated, and measured within companies. In this section, we discuss the evidence that has been published to date on the aspects of defensive marketing that have been studied.

Figure 1 shows linkages between customer retention and profits through the identified intervening factors of cost, increased purchases, price premium, and word-ofmouth communication. Reichheld and Sasser (1990) and others (Dawkins and Reichheld 1990; Rose 1990), who focused their attention on the association between customer retention and profits, identified these four intermediate factors. In addition to lower selling costs, existing customers who are happy with the company are likely to increase their purchases and buy other services and products from the company. They also may stay with the company even if the prices of the services they buy are increased. Finally, they tell other people about their positive experiences with the company, generating favorable word of mouth that subsequently reduces the marketing costs the company must expend to get additional customers.

Heskett, Sasser, and Schlesinger (1997) have conceptualized their research as the "service-profit chain." They argue that the longer customers stay with companies, the lower the costs to serve them, the higher the volume of purchases they make, the higher the price premium they tolerate, and the greater the positive word-of-mouth communication they engage in (see also Danaher and Rust 1996b). They have provided evidence from multiple companies such as Sears, Intuit, and Taco Bell to document these relationships. Customer loyalty can produce profit increases 
from 25 to 85 percent (Reichheld and Sasser 1990). In another study, Rose (1990) found that profits on services purchased by a 10-year customer were on average 3 times greater than those for a 5-year customer. Empirical studies of the service-profit chain (Loveman 1998; Rucci, Kirn, and Quinn 1998) support many aspects of this model.

Lowering customer defection rates can be profitable to companies. In fact, research has shown that retaining customers is a far more profitable strategy than gaining market share or reducing costs. In an empirical study linking customer satisfaction to profits, Fornell and Wernerfelt $(1987,1988)$ examined the impact of complaint-handling programs on customer retention and concluded that marketing resources were better spent keeping customers than attracting new ones. In support of this position, Reichheld and Sasser (1990) asserted that customer defections had a stronger impact on a company's profits than economies of scale, market share, unit costs, and other factors that lead to competitive advantage. The relationship between retention and profits has been documented by a variety of researchers (Anderson and Sullivan 1993; Fornell and Wernerfelt 1987, 1988; Reichheld and Sasser 1990) and companies (Heskett et al. 1997).

\section{DEFENSIVE EFFECTS OF SERVICE QUALITY: WHAT WE DO NOT KNOW}

Many issues about customer retention still remain to be examined. If we divide the issues in defensive marketing into two components-the association between service quality and retention and the association between retention and profits-it becomes apparent that most empirical research has dealt with the retention-profit link rather than the service-retention link. The tie between retention and profits has been studied far more often, probably because data to investigate that relationship exist in single or related databases (typically usage databases) in many companies. On the other hand, few companies have connected their perceived service quality or customer satisfaction databases to usage data because they lack customer information files (CIFs) that would allow the needed merging. Shown below are some of the specific questions that need to be answered about the defensive effects of service quality.

1. What is a loyal customer? As the focus on customer loyalty increases, the issue of defining loyal customers will need to be reexamined. A lengthy literature exists on this topic, most of which views customer loyalty either attitudinally or behaviorally. A simple behavioral approach is possible with some products and services: customers are loyal as long as they continue to use a good or service. For washing machines or long-distance telephone service, customers are deemed loyal if they continue to use the machine or telephone service. Defining customer loyalty for other products and services is more problematic. What is the definition of loyalty to a restaurant: always eat there, eat there more times than at other restaurants, or eat there at least once during a given period of time? These questions highlight the growing popularity of the concept of "share of wallet" that requires both definition and metrics. Another way to define loyalty is affectively-does the customer feel a sense of belonging or commitment to the product? Some companies have been noted for their "apostles," customers who care so much about the company that they stay in contact to provide suggestions for improvement and constantly preach to others the benefits of the company. Obviously, having ways to define and operationalize loyal customers behaviorally and affectively are necessary before we can accurately measure them.

2. What is the role of service in defensive marketing? Almost assuredly, service plays a critical role-if not the critical role-in retaining customers. Certainly having quality products at appropriate prices are important elements in the retention equation but both of these marketing variables can be imitated. Providing consistently good service is not as easy to duplicate and therefore is likely to be the cementing force in customer relationships. Academic research documenting this relationship is sparse, although managerial articles and books (e.g., Heskett et al. 1997) are convincing in their arguments. Only a few research studies have been conducted that explicitly link service quality with customer retention (for exceptions, see Ennew and Binks 1996; Rust and Zahorik 1993).

3. How does service compare in effectiveness to other retention strategies such as price? Statistical analysis that allows us to examine the relative contribution of different marketing variables in retention needs to be conducted. To date no studies have incorporated all or even most potential explanatory variables to examine their relative importance in keeping customers. ${ }^{3}$ A number of different methodologies could be appropriate for studying this question, including consumer questionnaires that examine the explained variance of customers' remaining with companies as a function of their assessments of companies' marketing mix. Many companies actually have survey data containing these variables but have either not analyzed the data for this purpose or have not reported their findings.

\section{What levels of service provision are needed to retain} customers? How much spending on service quality is enough to retain customers? Initial investigations into this question have been argued conceptually but have not been corroborated empirically. Coyne (1989), for example, proposed that when satisfaction rose above a certain threshold, repurchase loyalty would climb rapidly. When 
satisfaction fell below a different threshold, customer loyalty would decline equally rapidly. Between these thresholds, he believed that loyalty was relatively flat.

Zeithaml, Berry, and Parasuraman $(1993,1996)$ offered a different prediction. Viewing expectations as consisting of two levels, desired service (the level the customer hopes to receive, consisting of a blend of what the customer hopes can and should be delivered) and adequate service (the level of service the customer will accept), they conceived of a zone of tolerance capturing the range within which a company is meeting expectations.

The two frameworks differ. Coyne suggests that unless a company already has a strong reputation for service, it may not benefit by improving service much beyond the lower threshold. In contrast, Zeithaml et al. hypothesize that firms operating within the zone of tolerance should continue to improve service, even to the point of reaching the desired service level. This hypothesis implies an upward-sloping (rather than flat) relationship within the zone of tolerance.

Examining these and other possible relationships between service quality and loyalty is a priority for research. Blattberg and Deighton (1996) offer an economic model for the optimal level of spending to retain customers; while this model includes spending on all variables, an extension could focus solely on service quality.

5. How can word-of-mouth communication from retained customers be quantified? Word-of-mouth communication is perhaps the most difficult outcome of service and retention to gauge financially. Customer acquisition costs per customer saved by word of mouth can be estimated, as can the average number of customers acquired per customer sought through marketing. But the value of word-of-mouth communications is more far reaching than cost savings, particularly in services and particularly in experience or credence services. Consider, for example, how valuable word of mouth is to physicians or auto body shops or plastic surgeons. How many people are influenced by existing customers to try and use these services and what are the sales and profit outcomes of these communications? The chain of influence from word of mouth in services is a topic worthy of considerable study. Anderson (1998) has recently studied the influence of word-of-mouth communication on satisfaction. While not dealing directly with the financial implications, he provides an interesting quantitative assessment of the impact of both negative and positive word of mouth on customer perceptions.

6. What aspects of service are most important for customer retention? The only studies that have examined specific aspects of service and their impact on customer retention have been early studies looking at customer complaint management (Fornell and Wernerfelt 1987, 1988). A decade ago this was appropriate as service was often equated with customer service, the after-sale function that dealt with dissatisfied customers. However, service is multifaceted, consisting of a wide variety of customer-perceived dimensions including reliability, responsiveness, and empathy and resulting from several different company strategies such as technology and process improvement. In research exploring the relative importance of service dimensions on overall service quality or customer satisfaction, the bulk of the support confirms that reliability is most critical (Boulding, Kalra, Staelin, and Zeithaml 1993; Parasuraman, Zeithaml, and Berry 1988; Zeithaml et al. 1996), but others have demonstrated the importance of customization (Fornell et al. 1996) and other factors. Because the dimensions and attributes are delivered in many cases with totally different internal strategies, resources must be allocated where they are most needed, and research on this topic could provide direction.

7. How can defection-prone customers be identified? Companies report difficulty in creating and executing strategic systems responsive enough to changing circumstances to analyze customer defections (Jacob 1994). These systems must be developed to isolate potential defecting customers, to evaluate them, and to retain them if it is in the best interest of the company.

Customers who close their accounts and shift business to a competitor are easy to identify. Reichheld (1996a) advises that companies focus on two other harder-toidentify groups of customers who may be defection prone: (1) customers who shift some of their business to another firm and (2) customers who actually buy more but whose purchases represent a smaller share of their total expenditures. Heskett et al. (1997) also identified groups of potentially vulnerable customers: those with negative service experiences, new customers, and customers of companies in very competitive markets. Developing early warning systems for identifying such customers is a pivotal requirement for companies and a ripe area for research.

8. What is customers' tolerance for increased prices at different levels of service quality? As discussed above, Reichheld and Sasser (1990) claim that customers will be willing to pay a higher price if they are satisfied with the service provided by a company. This contention may have a limited life span. Consider that Firm A raises prices or margins for Customer $\mathrm{X}$ while providing good service. What if Firm $B$ engages in offensive marketing strategies to recruit Customer $\mathrm{X}$, using price as well as service as a tool? How might Customer $\mathrm{X}$ react? Customer $\mathrm{X}$ may think that Firm A took advantage of her. Research questions related to this scenario abound. How long will Customer $\mathrm{X}$ pay more? How much more? What happens in the face of price competition? Is Customer $\mathrm{X}$ angry? Does Customer X switch? 


\section{CUSTOMER PERCEPTIONS OF SERVICE QUALITY AND PURCHASE INTENTIONS}

While not shown in the figure, another construct mediates the service quality-profit association: purchase intentions. Researchers at Xerox uncovered a compelling insight about this relationship during its early years of customer satisfaction research. Initially, the company focused on satisfied customers, which they identified as those checking off either a 4 or a 5 on a 5-point satisfaction scale. Careful analysis of the data showed that customers giving Xerox $5 \mathrm{~s}$ were six times more likely to repurchase Xerox equipment than those giving $4 \mathrm{~s}$. This relationship encouraged the company to focus on increasing the $5 \mathrm{~s}$, rather than the combination of $4 \mathrm{~s}$ and $5 \mathrm{~s}$ because sales and profitability were likely to be increased significantly by this approach (Heskett et al. 1997).

Published research also offers evidence that customer satisfaction and/or service-quality perceptions positively affect intentions to behave in positive ways-praising the firm, preferring the company over others, increasing the volume of purchases, or agreeably paying a price premium. Most of the early research operationalized behavioral intentions in a unidimensional way rather than delineated specific types of behavioral intentions. Woodside, Frey, and Daly (1989), for example, found a significant association between overall patient satisfaction and intent to choose a hospital again. Anderson and Sullivan (1993), analyzing data from the Swedish Customer Satisfaction Barometer, found that stated repurchase intention was strongly related to stated satisfaction across virtually all product categories. Cronin and Taylor (1992), using a single-item purchase-intention scale, found a positive correlation with service quality and customer satisfaction.

Several academic studies have examined the association between service quality and more specific behavioral intentions. In a series of studies (see Parasuraman, Berry, and Zeithaml 1991b, 1994; Parasuraman, Zeithaml, and Berry 1988), researchers found a positive and significant relationship between customers' perceptions of service quality and their willingness to recommend the company. Boulding and colleagues (1993), in one of two studies they conducted, found a positive correlation between service quality and a two-item measure of repurchase intentions and willingness to recommend. In a second study involving university students, they found strong links between service quality and other behavioral intentions that are of strategic importance to a university, including saying positive things about the school, planning to contribute money to the class pledge upon graduation, and planning to recommend the school to employers as a place from which to recruit (Boulding, Kalra, Staelin, and Zeithaml 1992). Zeithaml et al. (1996) empirically examined the qualityintentions link using a behavioral-intentions battery composed of 13 specific behavioral intentions likely to result from perceived service quality. The battery was significantly correlated with customer perceptions of service quality. Most recently, Narayandas (1998) developed a benefits-of-customer-retention (BCR) ladder for the PC industry that demonstrated good psychometric properties.

Individual companies have also monitored the impact of service quality on selected behavioral intentions. Toyota found that intent to repurchase a Toyota automobile increased from a base of 37 percent to 45 percent with a positive sales experience, from 37 percent to 79 percent with a positive service experience, and from 37 percent to 91 percent with both positive sales and service experiences (McLaughlin 1993). A similar study by Gale (1992) quantitatively assessed the relationship between level of service quality and willingness to purchase at AT\&T. Of AT\&T's customers who rated the company's overall quality as excellent, more than 90 percent expressed willingness to purchase from AT\&T again. For customers rating the service as good, fair, or poor, the proportions decreased to 60 percent, 17 percent, and 0 percent, respectively.

\section{PERCEPTIONS OF SERVICE QUALITY, BEHAVIORAL INTENTIONS, AND FINANCIAL OUTCOMES: WHAT WE DO NOT KNOW}

Of all the relationships in the chain between service quality and profitability, the link between service quality and purchase intentions has been most often researched and confirmed. Customer questionnaires that study service quality can easily incorporate questions about purchase intentions, indicating perhaps that methodological ease accounts for the preponderance of research on this connection. However, the more compelling relationship between purchase intentions and actual purchase behavior lacks confirmation.

1. What is the relationship between customer purchase intentions and initial purchase behavior in services? It has long been known that customers do not always behave in ways they say they will; in general, they tend to overreport their intentions to buy products and services. They are also not particularly good predictors of their own behavior. Therefore, an important relationship to contemplate and capture is between purchase intentions and purchase behavior. The relationship between customer purchase intentions and initial purchase behavior will be one of the most difficult to document because to do so would mean matching data from customers before purchase (usually obtained anonymously) with postpurchase data. Postpurchase data can be collected through warranty cards or other means, but to try to connect these data to prepurchase intentions means having both customer identification and a mechanism to relate the two forms. One context in which 
this connection might be observed is with electronic services for which surveys are disseminated before purchases are made. Using e-mail or other electronic coding, a company could query survey participants about the desirability of a given service and then follow up to see if they purchase it.

2. What is the relationship between behavioral intentions and repurchase in services? This is a major linkage, and it involves relating customer satisfaction and perception data with purchase and usage data. If the relationship between service quality and retention can be substantiated, the financial implications of a satisfied customer can be studied, and the financial implications for an individual company or even a specific service initiative can be measured. Fortunately, this is a feasible research objective as companies make greater use of enterprise software and CIFs that link customer perception and usage databases in the company. Zeithaml, Rust, and Lemon (1999), for example, demonstrate the ability of a bank to merge its customer satisfaction and usage databases for market segmentation purposes. If a combination of customer perception and usage databases were analyzed over time, the relationship between intentions and behavior could be tracked along with other variables that might moderate the relationship such as unsatisfactory service experiences or discontinuation of company products and services.

3. Does the degree of association between service quality and behavior change at different quality levels? In the company studies by Toyota and AT\&T, dramatic increases were revealed in behavioral intentions as a result of increases in service quality perceptions. More valuable knowledge would be whether increases in service quality perceptions extend to equally impressive increases in actual purchase behavior. Despite the conceptual frameworks proposed for comprehending the impact of various levels of service provision, we have virtually no evidence about the empirical association. Surely this is a topic of primary importance both to companies wanting to understand resource investments and to researchers wanting to predict the impact of service quality on behavior.

\section{THE IMPACT OF SELECTING PROFITABLE CUSTOMERS}

Most published research on the connection between service quality and profitability has reported relationships in the aggregate rather than by segments or individual customers. This is understandable, for most service quality efforts in the past treated all customers alike, usually attempting to deliver high quality to all customers. Lately, however, both managers and scholars have come to believe that all customers are not alike. Viewing and serving all customers the same is a key reason why the tie between service quality and profitability has been elusive. Indivi- dual customer or tier profitability can have a moderating effect on the quality-profitability relationship.

In recent years, both scholars and managers have discussed the need to distinguish among levels or tiers of customers in providing service. Companies have successfully tiered customers by usage (often undertaking frequentflyer or frequent-buyer programs) in industries such as airlines, hotels, and rental car companies. Where heavy usage runs parallel to profitability, these programs are effective. However, many companies and industries are challenging that notion, discovering that heavy users require both high servicing and deep discounting, leading them to be less profitable than other categories of customers.

Reichheld (1993) showed that building a high-loyalty customer base of the right customers increased profits. At MBNA, a 5 percent increase in retention of the right customers grew the company's profits 60 percent during the ensuing 5-year period. In a later work, Reichheld (1996b) stated that companies must concentrate their efforts on that subset of customers to whom they can deliver consistently superior value. He suggests that companies isolate their core customers by asking (1) which customers are the most profitable and loyal, require less service, and seem to prefer stable, long-term relationships; (2) which customers place the greatest value on what you offer; and (3) which customers are worth more to you than to your competitors.

Revenues and price sensitivity are not the best ways to segment customers. Once a company adopts the tenet that a company should seek core customers over all others, price then becomes a "tool to filter out buyers who'll bolt for a penny" (Reichheld 1996a, p. 62). Several large service businesses, including Federal Express, recently renegotiated contracts with customers upon determining how unprofitable their relationships were; unless clients were willing to pay an acceptable margin of profit, companies like Federal Express ceased to serve them.

To segment on the basis of profitability, it becomes necessary to understand not only revenues but also persegment or per-customer acquisition spending. Blattberg and Deighton (1996) recommend that companies invest in the highest value customers first. In identifying prospects and customers, they claim that companies should "partition the base into behaviorally and attitudinally homogeneous groups that spend at different levels and ... estimate the shape of acquisition and retention curves for each group" (p. 140).

An example of effective use of the tiered service approach exists in a number of business contexts. Financial-services firms are leading the way, perhaps because of the vast amounts of data already housed in those firms. In 1994, Bank One realized that all financial institutions had grossly overcharged their best customers to subsidize others who were not paying their way. Determined to grow its top-profit customers, who were vulnerable because they 
were being underserved, they implemented a set of measures to focus resources on their most productive use. Next, they identified the profit drivers in this top segment and thereby stabilized their relationships with key customers (Hartfeil 1996). Another approach in the financialservices sector combined customer transactional data with market research on the same individuals. The resulting segmentation, known in the industry as FruitS, classified adults according to their likely use of financial services (Leventhal 1997). The underlying rationale for this approach was that once adults were classified, the company could more efficiently approach customers with services that have a greater certainty to be accepted.

Heskett et al. (1997) call this potential-based marketing, combining measures of loyalty with data describing potential levels of usage. Companies then attempt to increase shares of purchases by customers who either have the greatest need for the services or show the greatest loyalty to a single provider. By lengthening relationships with the loyal customers, increasing sales with existing customers, and increasing the profitability on each sale opportunity, they thereby increase the profitability of each customer.

\section{THE IMPACT OF SELECTING PROFITABLE CUSTOMERS: WHAT WE DO NOT KNOW}

Few rigorous academic studies have yet been published documenting the moderating effect of tiers of customers on profits. While both Reichheld (1996a, 1996b) and Blattberg and Deighton (1996) have offered arguments, heuristics, and methodologies for determining segment profitability, these methods need to be applied and their results disseminated to affirm these concepts. In one of the few academic studies conducted to demonstrating the importance of focusing on profitability with individual customers, Grant and Schlesinger (1995) estimated the full profit potential across tiers of customers. Using a Canadian grocery store context, they calculated the impact of expanding the customer base by 2 percent with primary shoppers: a profitability increase of more than 45 percent.

Much work remains to be done on this topic; indeed, developing the skill to tier customers may be the most essential step companies must take to link service quality and profitability. And the area is rich for academic inquiry-few of the important issues have even been posed to date, and virtually no empirical research has been published. Perhaps the most pivotal and basic questions that need to be examined are the following:

1. How can existing customers be identified in terms of profitability? To accomplish this, firms need to do two things. First, they must align information databases around the customer, using CIFs, rather than around products as is the traditional approach. Instead of data files being organized by product, with customers listed several times if they buy several products (e.g., a bank customer might be listed in a checking-account file, a savingsaccount file, a home-loan file, etc.), the data files must be organized by customer, with the products and affiliated revenues stored by customer. Many firms, especially financial and business-to-business firms, have begun to store product revenues by customer and are therefore able to examine customer tiers as described in the examples above. The second necessity is to understand, to record, and to store the costs associated with each customer in their customer files, a daunting task for service firms. While the accounting approach of activity-based costing $(\mathrm{ABC})$ is useful, in many cases the allocation of service costs to customers is arbitrary at best. Ultimately, it is necessary that the management information system include a summary profitability figure for each customer that can be accessed easily. This is the number that is used to construct the customer tiers and that will be a guide as to how to best manage the customer relationship with each customer (see Zeithaml et al. 1999 for more details).

An excellent example of the types of rigorous approaches to analyzing the profitability of particular customer relationships has been developed by Storbacka (1992, 1993, 1994a, 1994b). Focusing on the difficult problem of allocating costs to specific relationships, he argued that the most important cost drivers are the episodes (encounters) in relationships and provided a method to systematically analyze relationships (called episodic configuration). Analytical approaches like this one that can be subsequently tested empirically are important to moving the body of research in the right direction.

2. How can potential customers be identified in terms of profitability? As difficult as identifying existing customers is in terms of profitability, it is even more difficult to identify potential customers who will ultimately be in the top tiers. Developing a profile of the potentially profitable customer will likely require a combination of understanding existing profitable customers, delineating demographic and psychographic variables that predict profitability, and creating and testing strategic approaches to obtain and qualify customers. To date, little if any empirical work has been reported on this topic.

3. How can customers be tiered in terms of profitability? Enterprise software that links company information such as perceptual, usage, and financial data will be invaluable for companies that want to segment customers on the basis of profitability. Companies would likely need to identify three or four profitability segments or tiers and then make choices about how to serve them differentially to reflect their lifetime profit contributions to the company. At times, this segmentation may reveal one or more segments that are not profitable to the company and therefore need to be examined for ways to deliver service to them 
more efficiently. It is often possible to make each level profitable, devoting greater resources to the most profitable segments and matching resources to profits in the other segments. As an example, banks are currently using software to identify their most important (A) customers, the largest lenders and depositors, and their least profitable (D) customers. They have chosen a profit-making strategy for the D customers, who are often students: they offer a special account where only the ATM and telephone are used, and where high fees (as much as $\$ 30$ ) are charged for overdrafts or failures to make payments on overdraft checking accounts. In this manner, they save their personal service efforts for their best customers and yet still retain the D customers without losing exorbitant amounts of money on them.

4. What demographic and psychographic variables are most effective in characterizing profitability tiers? Once firms identify profitability segments, they need to be able to characterize these segments into identifiable, measurable, and accessible groups of customers. This is particularly true with companies who deal with end consumers, for these companies must look out at a vast array of potential customers and decide whom to market to and whom to focus on once they have a set of customers. Among industries, telecommunications and banking are ahead in these efforts, and more generalizable approaches are needed for other industries. Database technology and "data mining"-described as the "automated discovery of "interesting, non-obvious patterns hidden in a database that have a high potential for contributing to the bottom line" (Peacock 1998)-are useful here.

5. What service variables are drivers of financial performance in each tier? One of the most fascinating issues in this category is whether service drivers are the same in different service tiers. The single academic study to date (Zeithaml et al. 1999) suggests that they are not. Customers in two different tiers view quality differently. For the top tier, a factor called speed (which involved how quickly the customer was served) was key to driving incidences of new business, while for the lower tier, a factor called attitude (involving the way the customer was treated by employees) was the driver. Analysis showed that combining the two tiers would result in a muddied picture that would identify drivers unlikely to satisfy either tier.

\section{IDENTIFYING THE KEY DRIVERS OF SERVICE QUALITY, CUSTOMER RETENTION, AND PROFITS}

Understanding the relationship between overall service quality and profitability is important, but it is perhaps more useful managerially to identify specific drivers of service quality that most relate to the dependent and intervening variables. Doing so will help firms understand what aspects of service quality to change to influence the relationship, and therefore where to invest resources.

The relevant stream of research in marketing has examined the impact of aspects of service on perceptual dependent variables (including overall service quality, customer satisfaction, and purchase intentions) rather than on retention or profitability. This research has been approached in several different ways. First, researchers have examined the service dimensions and attributes that most influence overall service quality (Bolton and Drew 1991a, 1991b; Parasuraman et al. 1988; Rust, Keiningham, Clemens, and Zahorik 1998). Others have viewed the impact of specific service encounters on overall service quality or customer satisfaction (Bolton 1998; Bolton and Drew 1994; Fornell and Wernerfelt 1987, 1988) and the impact of specific behaviors within service encounters (Bitner, Booms, and Tetreault 1990).

Another stream of research, based largely in the operations and management literatures, has investigated the impact of service programs and managerial approaches within an organization on dependent measures, some of them profitability measures. For example, Fitzerald and Erdmann (1992) estimated the impact of continuous improvement on profits in $\mathbf{2 8 0}$ automotive suppliers and found a 17 percent increase in profits during a 2- to 3-year period. Mann and Kehoe (1994) revealed that delegated teams were particularly effective at improving people and that statistical process control was most effective in improving processes in TQM programs. Ittner and Larcker (1997) explored the cross-sectional association between process management techniques and profit measures (return on sales and ROA) and found that a long-term partnership with suppliers and customers is associated with higher performance. Furthermore, they found that other techniques (e.g., statistical process control, process capability studies, and cycle time analysis) vary by industry and are not universally related to the performance measures. A marketing study in this stream was conducted by Hauser, Simester, and Wernerfelt (1994), who demonstrated analytically the financial implications of using customer satisfaction in employee incentive systems.

Rust et al. (1995) provided a framework, called the return on quality (ROQ) approach, for examining the impact of service quality improvements on profits that is unique in that it begins with the key drivers of service and extends all the way to profits. Using the ROQ approach, they showed that the behavioral impact stemming from service quality leads to improved profitability and other financial outcomes. They begin by gauging a service improvement effort that produces an increased level of customer satisfaction at the process or attribute level (e.g., Bolton and Drew 1991a, 1991b; Rust et al. 1998; Simester, Hauser, Wernerfelt, and Rust 1998). Increased customer satisfaction at the process or attribute level then leads to increased overall customer satisfaction or perceived 
service quality (Keiningham, Zahorik, and Rust 19941995; Kordupleski et al. 1993; Rust et al. 1995). Higher overall service quality or customer satisfaction leads to increased behavioral intentions, such as greater repurchase intention (Boulding et al. 1993), willingness to recommend (Danaher and Rust 1996b; Zeithaml et al. 1996), and intention to increase usage (Bolton and Lemon 1999; Danaher and Rust 1996a, 1996b). Increased behavioral intentions lead to behavioral impact, including repurchase or customer retention (Bolton 1998; Reichheld and Sasser 1990; Rust and Zahorik 1993), positive word of mouth (Oliver and Swan 1989; Swan and Oliver 1989), and increased usage (Bolton and Lemon 1999; Danaher and Rust 1996a).

Behavioral impact then leads to improved profitability and other financial outcomes (Rust et al.1995; Zahorik and Rust 1992).

\section{IDENTIFYING THE KEY DRIVERS OF SERVICE QUALITY, CUSTOMER RETENTION, AND PROFITS: WHAT WE DO NOT KNOW}

Many research questions remain.

1. What service encounters are most responsible for perceptions of service quality? Of all the service encounters experienced by customers of a firm, which are most important? Almost no academic research investigates this question although individual companies have studied the issue. Marriott Hotels, for example, conducted extensive customer research to determine what service elements contribute most to customer loyalty. They found that four of the top five factors came into play in the first 10 minutes of the guest's stay, those that involved the early encounters of arriving, checking in, and entering the hotel rooms. Other companies have found that mistakes or problems that occur in early service encounters are particularly critical, because a failure at early points results in greater risk for dissatisfaction in each ensuing encounter. Both AT\&T and IBM found that the sales encounter was the most critical of all, in large part because salespeople establish expectations for the remaining service encounters. Academic research that tests this hypothesis and examines the relative importance of different service encounters across industries is greatly needed.

2. What are the key drivers in each service encounter? Almost all of the research cited above studies the key drivers of an overall service relationship rather than individual service encounters. A rare exception is Kordupleski et al. (1993), which reports work at AT\&T about the key service encounters and the three most critical drivers in each encounter. To be operational, companies need to be able to identify the service encounters where problems occur and then the key drivers in each of these encounters. One key guideline for research and practice on this topic is that it must detail drivers involving specific behaviors of service contact personnel rather than abstract service dimensions such as reliability (see Zeithaml and Bitner 2000).

3. Where should investments in service quality be made to have the greatest impact on service quality, purchase, customer retention, and financial outcomes? Of all the company strategies, processes, approaches, and tactics that can be altered, where should companies invest money? The methodology outlined by Rust et al. (1995) is informative because it can be applied in companies to direct their individual strategies. The collective results of such studies can be examined for patterns within and across industries. Huge progress can be made in this area using the ROQ framework because it provides a solid structure for guiding practice and research.

4. Are key drivers of service quality the same as key drivers of behavioral intentions, customer retention, and profits? The research investigating the drivers of service quality and customer satisfaction requires verification as to whether results are the same when customer retention and profits are the dependent variables. Intuitively, this appears to be logical and obvious at the individual customer level, yet it may not hold when considering customers at the collective level. Storbacka and Luukinen (1996) found that customer satisfaction was higher among the most unprofitable customers in the customer base, implying a disconnect between perceptual and financial variables.

\section{SUMMARY}

Table 2 shows the full inventory of research questions that this article suggests are needed to understand the relationships among service quality, profitability, and the economic worth of customers. Each of these questions was discussed in the text of the article after reviewing what we know about the six topics most relevant in understanding the relationship. In a general sense, each section can be summarized as follows:

1. In terms of the direct relationship between service quality and profits, what we know is that both positive and negative relationships have been confirmed. What we need to learn is what marketing and managerial variables moderate the relationship.

2. The offensive effects of service quality require considerable research for most of what is currently known comes from the PIMS database with its inherent limitation of no direct measure of perceived service quality. 
3. For the defensive effects of service quality, what we know is that retention positively affects profits (through lowered costs, increased purchases, willingness to pay a price premium, and positive word of mouth), but we need to learn how service quality variables influence retention and its financial outcomes.

4. The relationship between service quality and purchase intentions has sparked sufficient research linking perceptual measures of service quality and purchase intentions but insufficient work tying purchase intentions to purchase behaviors.

5. In terms of individual customer and segment profitability, what we know is that all customers are not equally profitable. We need to learn how to identify, to reach, and to respond to customers at different levels of profitability.

6. For key drivers of service quality, customer retention and profits, we know the key drivers of service quality but we need to learn the key drivers of behavioral intentions, purchase, customer retention, and financial outcomes.

While some progress has been made in the past 10 years in investigating service quality, profitability, and the economic worth of customers, much research remains to be done to validate this early evidence and to build a coherent and integrated body of knowledge. This article has provided a conceptual framework that links the variables that need to be studied in an effort to clarify where research is needed. Many opportunities for improvement on this framework and for future empirical research exist.

\section{NOTES}

1. Customer satisfaction and perceived service quality have been acknowledged to be strongly related but somewhat conceptually different constructs (see Bolton and Drew 1991b; Cronin and Taylor 1992; Parasuraman, Berry, and Zeithaml 1994). However, the author chose not to focus on the distinction between perceived service quality and customer satisfaction because multiple other articles describe and delineate the two constructs and because in practice the two are treated as virtually the same. Since this article has a broader perspective-that of linking service quality to profits--relevant research relating customer satisfaction and profitability is introduced and weaved into the model. In particular, work by Fornell and colleagues discussed in this section has moved the field forward considerably; furthermore, customer variables such as expectations, perceived quality, perceived value, and purchase intentions are also measured in their work (see especially Fornell 1992 and Fornell, Johnson, Anderson, Cha, and Bryant 1996).

2. It is possible that there exists some understatement of zero or nonsignificant effects due to a "file drawer" problem - the tendency not to publish research that does not show significant associations. Unfortunately, the extent of this effect is not possible to estimate.

3. The same price-versus-service issue is central to behavioral intentions and to financial outcomes, and has not received sufficient research attention in those areas either.

\section{REFERENCES}

Aaker, David A. and Robert Jacobson. 1994. "The Financial Information Content of Perceived Quality." Journal of Marketing 58 (May): 191-201.

Anderson, Eugene W. 1998. "Customer Satisfaction and Word of Mouth." Journal of Service Marketing 1 (1): 5-17.

—, Claes Fomell, and Donald R. Lehmann. 1994. "Customer Satisfaction, Market Share and Profitability." Journal of Marketing 58 (July): 53-66.

and Mary Sullivan. 1993. "The Antecedents and Consequences of Customer Satisfaction for Firms." Marketing Science 12 (Spring): 125-143.

Andreassen, Tor Wallen and Bodil Lindestad. 1998. "The Effect of Corporate Image in the Formation of Customer Loyalty." Journal of Service Research 1 (1): 82-92.

Bitner, Mary Jo, Bernard H. Booms, and Mary Stanfield Tetreault. 1990. "The Service Encounter: Diagnosing Favorable and Unfavorable Incidents." Journal of Marketing 54 (1): 71-84.

Blattberg, Robert C. and John Deighton. 1996. "Manage Marketing by the Customer Equity Test." Harvard Business Review (July-August): 136-144.

Bohan, George P. and Nicolas F. Horney. 1991. "Pinpointing the Real Cost of Quality in a Service Company." National Productivity Review 10 (3): 309-317.

Bolton, Ruth. 1998. "A Dynamic Model of the Duration of the Customer's Relationship with a Continuous Service Provider: The Role of Satisfaction." Marketing Science 17 (Winter): 45-65.

____ and James H. Drew. 1991a. "A Longitudinal Analysis of the Impact of Service Changes on Customer Attitudes." Journal of Marketing 55 (January): 1.9.

and 1991b. "A Multistage Model of Customers' Assessment of Service Quality and Value." Journal of Consumer Research 17 (March): 375-384

and 1994. "Linking Customer Satisfaction to Service Operations and Outcomes." In Service Quality: New Directions in Theory and Practice. Eds. R. T. Rust and R. L. Oliver. London: Sage, 79-94.

_ and Katherine N. Lemon. 1999. "A Dynamic Model of Customers' Usage of Services: Usage as an Antecedent and Consequence of Satisfaction." Joumal of Marketing Research 36 (May): 171-186.

Boulding, William, Ajay Kalra, Richard Staelin, and Valarie A. Zeithaml. 1992. "Conceptualizing and Testing a Dynamic Process Model of Service Quality." Report Number 92-121. Marketing Science Institute, Cambridge, MA.

, of Service Quality: From Expectations to Behavioral Intentions." Journal of Marketing Research 30 (February): 7-27.

Bounds, Greg, Lyle York, Mel Adams, and Gipsie Ranney. 1994. Beyond Total Quality Management Toward the Emerging Paradigm. New York: McGraw-Hill.

Buzzell, Richard and Bradley Gale. 1987. The PIMS Principles: Linking Strategy to Performance. New York: Free Press.

Carr, Lawrence P. 1992. "Applying Cost of Quality to a Service Business." Sloan Management Review 33 (4): 72-77.

Cox, E. 1980. "The Optimal Number of Response Alternatives for a Scale: A Review." Journal of Marketing Research 17 (4): 407-422.

Coyne, Kevin P. 1989. “Beyond Service Fads: Meaningful Strategies for the Real World." Sloan Management Review 30 (4): 69-76.

"The Cracks in Quality." 1992. The Economist 18 (April): 67-68.

Cronin, J. Joseph and Steven A. Taylor. 1992. "Measuring Service Quality: A Re-Examination and Extension." Joumal of Marketing 56 (July): 55-68.

Crosby, Philip B. 1979. Quality Is Free. New York: McGraw-Hill.

Danaher, Peter J. and Roland T. Rust. 1996a. "Determining the Optimal Return on Investment for an Advertising Campaign." European Journal of Operational Research 95 (3): 511-521.

and 1996b. "Indirect Financial Benefits From Service Quality." Quality Management Journal 3 (2): 63-85.

Darby, M. R. and E. Karni. 1973. "Free Competition and the Optimal Amount of Fraud." Journal of Law and Economics 16 (April): 67-86. 
Dawkins, Peter and Frederick F. Reichheld. 1990. "Customer Retention as a Strategic Weapon." Directors and Boards 14 (Summer): 41-47.

Deming, W. Edwards. 1986. Quality Productivity and Competitive Position. New York: Free Press.

Easton, George S. 1993. "The 1993 State of U.S. Total Quality Management: A Baldrige Examiner's Perspective." California Management Review 35 (3): 32-54

and Sherry L. Jarrell. 1998. "The Effects of Total Quality Management on Corporate Performance." Journal of Business 71 (April): 253-308.

Ennew, Christine T. and Martin R. Binks. 1996. "The Impact of Service Quality and Service Characteristics on Customer Retention: Small Businesses and Their Banks in the UK." British Journal of Management 7 (September): 219-230.

Fitzerald, C. and T. Erdmann. 1992. Actionline. American Automotive Industry Action Group (October).

Ford Motor Company. 1990. Memorandum to Dealers (October 3).

Fornell, Claes. 1992. "A National Customer Satisfaction Barometer: The Swedish Experience." Journal of Marketing 56 (January): 6-21.

___ and Birger Wernerfelt. 1987. "Defensive Marketing Strategy by Customer Complaint Management: A Theoretical Analysis." Journal of Marketing Research 24 (November): 337-346.

— and 1988. "A Model for Customer Complaint Management." Marketing Science 7 (Summer): 271-286.

_- Michael D. Johnson, Eugene W. Anderson, Jaesung Cha, and Barbara Everett Bryant. 1996. "The American Customer Satisfaction Index: Nature, Purpose and Findings." Journal of Marketing 60 (October): 7-18.

Gale, Bradley. 1992. "Monitoring Customer Satisfaction and MarketPerceived Quality." Worth Repeating Series, No. 922CSO1. Chicago, American Marketing Association.

Grant, Alan W. and Leonard A. Schlesinger. 1995. "Realize Your Customer's Full Profit Potential." Harvard Business Review 73 (September-October): 59-72.

Greising, David. 1994. "Quality_How to Make It Pay." Business Week, August 8, pp. 54-59.

Hallowell, Roger. 1996. "The Relationship of Customer Satisfaction, Customer Loyalty, and Profitability: An Empirical Study." International Journal of Service Industry Management 7 (4): 27-42.

Hartfeil, Guenther. 1996. "Bank One Measures Profitability of Customers, Not Just Products." Journal of Retail Banking Services 18 (2): 24-31.

Hauser, John R., Duncan I. Simester, and Birger Wernerfelt. 1994. "Customer Satisfaction Incentives." Marketing Science 16 (Spring): 129-145.

Hendricks, Kevin B. and Vinod R. Singhal. 1997. "Does Implementing an Effective TQM Program Actually Improve Operating Performance? Empirical Evidence From Firms That Have Won Quality Awards." Management Science 43 (9): 1258-1274.

Heskett, James L., W. Earl Sasser, Jr., and Leonard A. Schlesinger. 1997. The Service Profit Chain. New York: Free Press.

Ittner, Christopher and David F. Larcker. 1996. "Measuring the Impact of Quality Initiatives on Firm Financial Performance." In Advances in the Management of Organizational Quality, Vol. 1. Eds. Soumeh Ghosh and Donald Fedor. Greenwich, CT: JAI, 1-37.

- and - 1997. "The Performance Effects of Process Management Techniques." Management Science 43 (4): 523-534

Jacob, Rahul. 1994. "Why Some Customers Are More Equal Than Others." Fortune, September 19, pp. 215-224.

Jacobson, Robert and David A. Aaker. 1987. "The Strategic Role of Product Quality." Journal of Marketing 51 (October): 31-44.

Keiningham, Timothy, Anthony J. Zahorik, and Roland T. Rust. 1994/1995. "Getting Return on Quality." Journal of Retail Banking Services 16 (40): 7-12.

Kordupleski, Raymond E., Roland T. Rust, and Anthony J. Zahorik. 1993. "Why Improving Quality Doesn't Improve Quality (or Whatever Happened to Marketing?)." California Management Review 35 (3): 82-95.

Koska, Mart T. 1990. "High Quality Care and Hospital Profits: Is There a Link?" Hospitals (March 5): 62-63.

Leventhal, Barry. 1997. "An Approach to Fusing Market Research With Database Marketing." Journal of the Market Research Society 39 (4): 545-558.
Loveman, Gary W. 1998. "Employee Satisfaction, Customer Loyalty, and Financial Performance: An Empirical Examination of the Service Profit Chain in Retail Banking." Journal of Service Research 1 (1): 18-31.

Mann, Robin and Dennis Kehoe. 1994. "An Evaluation of the Effects of Quality Improvement Activities on Business Performance." The International Journal of Quality and Reliability Management 11 (4): 29-45.

Matthews, J. and P. Katel. 1992. "The Cost of Quality: Faced With Hard Times, Business Sours on Total Quality Management." Newsweek (September 7): 48-49.

McLaughlin, John P. 1993. "Ensuring Customer Satisfaction Is a Strategic Issue, Not Just an Operational One." Presentation at the AIC Customer Satisfaction Measurement Conference, Chicago, December 6-7.

Narayandas, Das. 1998. "Measuring and Managing the Benefits of Customer Retention: An Empirical Investigation." Joumal of Service Research 1 (2): 108-128.

Nelson, Eugene, Roland T. Rust, Anthony Zahorik, Robin L. Rose, Paul Batalden, and Beth Siemanski. 1992. "Do Patient Perceptions of Quality Relate to Hospital Financial Performance?" Journal of Healthcare Marketing (December): 1-13.

Nelson, Philip. 1970. "Information and Consumer Behavior." Journal of Political Economy 78 (20): 311-329.

Oliver, Richard L. and John E. Swan. 1989. "Consumer Perceptions of Interpersonal Equity and Satisfaction." Journal of Marketing 53 (April): 21-35.

Parasuraman, A., Valarie A. Zeithaml, and Leonard L. Berry. 1985. "A Conceptual Model of Service Quality and Its Implications for Future Research." Journal of Marketing 49 (Fall): 41-50.

$\longrightarrow$, and 1988. "SERVQUAL: A Multiple-Item Scale for Measuring Consumer Perceptions of Service Quality." Journal of Retailing 64 (Spring): 12-40.

—, Leonard L. Berry, and Valarie A. Zeithaml. 1991a. "Perceived Service Quality as a Customer-Based Performance Measure: An Empirical Examination of Organizational Barriers Using an Extended Service Quality Model." Human Resource Management 30 (Fall): 335-364.

_ 1991b. "Refinement and Reassessment of the SERVQUAL Scale." Journal of Retailing 67 (Winter): 420-450. , and - 1994. "Moving Forward in Service Quality Research: Measuring Different Levels of Customer Expectations, Comparing Alternative Scales, and Examining the PerformanceBehavioral Intentions Link." MSI Working Paper No. 94-114 (September). Marketing Science Institute, Cambridge, MA

Peacock, Peter R. 1998. "Data Mining in Marketing: Part 1." Marketing Management 6 (Winter): 9-18.

Peters, Thomas J. 1988. Thriving on Chaos. New York: Knopf,

Phillips, Lynn, Dae R. Chang, and Robert Buzzell. 1983. "Product Quality, Cost, and Business Performance: A Test of Some Key Hypotheses." Journal of Marketing 47 (Spring): 26-43.

Reger, Rhonda K., L. T. Gustafson, S. M. Demarie, and J. V. Mulland 1994. "Reframing the Organization: Why Implementing Total Quality Is Easier Said Than Done." Academy of Management Review 19 (3): 565-584.

Reichheld, Frederick. 1993. "Loyalty-Based Management." Harvard Business Review 71 (March-April): 64-74.

_. 1996a. "Learning From Customer Defections." Harvard Business Review 74 (March-April): 56-69.

. 1996b. The Loyalty Effect: The Hidden Force Behind Growth, Profits, and Lasting Value. Boston: Harvard Business School Press. and W. Earl Sasser, Jr. 1990. "Zero Defections: Ouality Comes to Services." Harvard Business Review 68 (September-October): 105111.

Richardson, Paul S., Alan S. Dick, and Arun K. Jain. 1994. "Extrinsic and Intrinsic Cue Effects on Perceptions of Store Brand Quality." Journal of Marketing 58 (October): 28-37.

Rose, S. 1990. "The Coming Revolution in Credit Cards." Journal of Retail Banking 12 (Summer): 17-19.

Rucci, Anthony J., Steven P. Kirn, and Richard T. Quinn. 1998. "The Employee-Customer Profit Chain at Sears." Harvard Business Review 76 (January-February): 84-97. 
Rust, Roland, Bala Subramanian, and Mark Wells. 1992. "Making Complaints a Management Tool." Marketing Management 1 (3): 40-45.

and Anthony J. Zahorik. 1993. "Customer Satisfaction, Customer Retention, and Market Share." Journal of Retailing 69 (Summer): 193-215.

_ a a Timothy Keiningham. 1995. "Return on Quality (ROQ): Making Service Quality Financially Accountable." Journal of Marketing 59 (April): 58-70.

Timothy Keiningham, Stephen Clemens, and Anthony Zahorik. 1998. "Return on Quality at Chase Manhattan Bank." Working Paper. Center for Service Marketing, Vanderbilt University, Nashville, TN

Ryan, M. J., T. Buzas, and V. Ramaswamy. 1995. "Making CSM a Power Tool." Marketing Research: A Magazine of Management and Application 7 (3): 11-16.

Simester, Duncan I., John R. Hauser, Birger Wernerfelt, and Roland T. Rust. 1998. "Implementing Quality Improvement Programs Designed to Enhance Customer Satisfaction: Quasi-Experiments in the U.S. and Spain." Working Paper. Massachusetts Institute of Technology, Sloan School of Management, Cambridge.

Sterman, John D., Nelson P. Repenning, and Fred Kofman. 1997. "Unanticipated Side Effects of Successful Quality Programs: Exploring a Paradox of Organizational Improvement." Management Science 43 (4): 503-521.

Storbacka, K. 1992. "Developing Service Business Processes." Working Paper No. 250. Swedish School of Economics and Business Administration, Helsinki, Finland.

1993. Customer Relationship Profitability in Retail Banking. Research Report No. 29. Helsinki, Finland: Swedish School of Economics and Business Administration.

1994a. "Analyzing the Profitability Distribution of Customer Bases in Retail Banks-The Storbachoff Index." Working Paper No. 56. Swedish School of Economics and Business Administration, Helsinki, Finland.

- 1994b. "The Nature of Customer Relationship Profitability Analysis of Relationships and Customer Bases in Retail Banking." Working Paper. Swedish School of Economics and Business Administration, Helsinki, Finland.

and A. Luukinen. 1996. "Managing Customer Relationship Profitability - Case Swedbank." In Proceedings From Banking and Insurance: From Recession to Recovery. Amsterdam: ESOMAR, 79-93.

Swan, John E., and Richard L. Oliver. 1989. "Postpurchase Communications by Customers.” Journal of Retailing 65 (Winter): 516-533.
U.S. General Accounting Office. 1991. Management Practice, U.S. Companies Improve Performance Through Quality Efforts. Report No. GAO/NSIAD-91-190. Washington, DC: General Accounting Office.

Woodside, A., L. Frey, and R. Daly. 1989. "Linking Service Quality, Customer Satisfaction and Behavioral Intentions." Journal of Health Care Marketing 9 (December): 5-17.

Zahorik, Anthony J. and Roland T. Rust. 1992. "Modeling the Impact of Service Quality on Profitability: A Review." In Advances in Service Quality and Management, Vol. 1. Ed. Terry Schwartz. Greenwich, CT: JAI, 247-276.

Zeithaml, Valarie A. 1981. "How Consumer Evaluation Processes Differ Between Goods and Services." In The Marketing of Services, Proceedings of the 1981 National Services Conference. Ed. J. Donnelly. Chicago: American Marketing Association, 186-190. - and Mary Jo Bitner. 2000. Services Marketing. Burr Ridge, IN: McGraw-Hill

, Leonard L. Berry, and A. Parasuraman. 1993. "The Nature and Determinants of Customer Expectations of Service." Journal of the Academy of Marketing Science 21 (Winter): 1-12.

, 1 , and $\longrightarrow$ 1996. "The Behavioral Consequences of Service Quality." Journal of Marketing 60 (April): 31-46.

, Roland T. Rust, and Kay Lemon. 1999. "Make Customer Profitability the Basis for Service." Working Paper. University of North Carolina at Chapel Hill.

\section{ABOUT THE AUTHOR}

Valarie A. Zeithaml is Professor, Area Chair of Marketing and Sarah Graham Kenan Distinguished Scholar at the KenanFlagler Business School of the University of North Carolina, Chapel Hill. She obtained an MBA and doctorate from the University of Maryland and has devoted the past 20 years to researching and teaching the topics of service quality and services management. She has won numerous teaching and research awards, including the Ferber Award from the Journal of Consumer Research, the Maynard Award from the Journal of Marketing, the Jagdish Sheth Award from the Journal of the Academy of Marketing Science, and the O'Dell Award from the Journal of Marketing Research. 